\title{
Oxidative stress biomarkers and aggressive behavior in fish exposed to aquatic cadmium contamination
}

\author{
Jeane A. Almeida ${ }^{1}$, Rodrigo E. Barreto ${ }^{2}$, Ethel L. B. Novelli ${ }^{2}$, Fabio J. Castro ${ }^{1}$ \\ and Sandro E. Moron ${ }^{1}$
}

The objective of this study was to investigate the possible link between cadmium exposure, hepatic markers of oxidative stress and aggressive behavior in Nile tilapia (Oreochromis niloticus). Fish were first exposed to $0.75 \mathrm{mg} / \mathrm{L} \mathrm{CdCl}_{2}$ for 15 days (12 isolated fish for each group) and afterward a behavioral test was performed. Fish from the control and cadmium-exposed groups were paired for $1 \mathrm{~h}$ ( 6 pairs of fish per group) for determination of aggressiveness parameters. Immediately after the behavioral test, the animals were sacrificed and the liver was used to determine biochemical parameters. Cadmium decreased aggression in Nile tilapia. Subordinate animals exposed to cadmium showed decreased glutathione peroxidase (GSH-Px) activity compared to dominant ones. No alterations were observed in selenium-dependent glutathione peroxidase Se-GSH-P and $\mathrm{Cu}-\mathrm{Zn}$ superoxide dismutase activities, but total superoxide dismutase activity was increased in subordinate animals exposed to cadmium compared to subordinate control. Catalase activity was increased in cadmium-exposed fish. Lipoperoxide concentrations also increased in cadmium exposed fish indicating that cadmium toxicity may affect oxidative stress biomarkers in Nile tilapia. Social stress induced lipoperoxidation in Nile tilapia, and subordinate animals exposed to cadmium responded with lower activities of liver antioxidant enzymes compared to dominant fish. The present study shows that cadmium exposure is capable of inducing changes in the social status and oxidative stress parameters in this species.

O objetivo deste estudo foi investigar a possível relação entre a exposição ao cádmio, os marcadores hepáticos de estresse oxidativo e o comportamento agressivo em tilápia do Nilo (Oreochromis niloticus). Os peixes foram primeiramente expostos à concentração de $0,75 \mathrm{mg} / \mathrm{L}$ de $\mathrm{CdCl}_{2}$ durante 15 dias (12 peixes isolados em cada grupo), após o qual o teste de comportamento foi aplicado. Peixes do grupo controle e do grupo exposto ao cádmio foram pareados durante 1 hora (6 pares de peixes por grupo) para determinação de parâmetros de agressividade. Imediatamente após o teste comportamental, os animais foram sacrificados e o fígado foi coletado para as determinações bioquímicas. O cádmio diminuiu a agressão em tilápias do Nilo. Animais subordinados e expostos ao cádmio mostraram uma redução na atividade da enzima glutationa peroxidase (GSH-Px), quando comparados aos dominantes. Nenhuma alteração foi observada na atividade da glutationa peroxidase dependente de selênio (Se-GSH-P) e na superóxido dismutase $\mathrm{Cu} \mathrm{Zn}$, mas a atividade total da superóxido dismutase aumentou em animais subordinados e expostos ao cádmio, quando comparado ao controle subordinado. A atividade da catalase aumentou em peixes expostos ao cádmio. As concentrações de lipoperóxido aumentaram em peixes expostos ao cádmio, indicando que a toxicidade deste pode afetar os biomarcadores de estresse oxidativo em tilápias do Nilo. O estresse social induziu lipoperoxidação em tilápia do Nilo e animais subordinados e expostos ao cádmio responderam com baixas atividades de enzimas antioxidantes hepáticas do que em peixes dominantes. O presente estudo mostra que a exposição ao cádmio é capaz de induzir alterações no status social e nos parâmetros de estresse oxidativo nesta epécie.

Key words: Oreochromis niloticus, Stress response, Antioxidant enzymes, Social stress, Liver, Nile tilapia.

\section{Introduction}

The use of pollution biomarkers has been the subject of several studies, especially due to the fact that distinct kinds of pollutants may interfere with animal physiology and behavioral processes, which in turn is of ecological importance (Scott \& Sloman, 2004).

The contamination of water by metal compounds is a worldwide environmental problem. Heavy metals, such as cadmium, are released into the environment by industries and

${ }^{1}$ Universidade Federal do Tocantins, UFT, BR 153, Km 112, Cx. Postal 132, 77804-970 Araguaína,Tocantins, Brazil. jeane@uft.edu.br (JAA), fabiuscastrus@yahoo.com.br (FJC), sandromoron@uft.edu.br (SEM)

${ }^{2}$ Departamento de Fisiologia, Instituto de Ciências Biológicas, UNESP, Botucatu, São Paulo, Brazil. rodrigo.sbarreto@yahoo.com.br (REB), ethel.novelli@pd.cnpq.br (ELBN) 
reach streams and rivers via run-off from unregulated waste disposal (Nriagu et al., 1998). Cadmium is a highly toxic heavy metal, since it causes deleterious effects in organisms at low levels of exposure (Cope et al., 1994). Various toxic effects of cadmium have been reported, as well as its accumulation in liver (Novelli et al., 1998), kidney (Klaassen \& Liu, 1997; Novelli et al., 1999) and testes (Shen \& Sangiah, 1995).

Several studies show that toxic agents may affect behavioral parameters (Abdul Farah et al., 2004; Lefebvre et al., 2004; Nakayama et al., 2004; Yilmaz et al., 2004; Sloman et al., 2003). Behavioral changes are good indicators of damage to the central nervous system, as a consequence of exposure to toxic agents (Sloman et al., 2003). According to Provias et al. (1994), toxic effects of cadmium in the brain and nervous system may be associated with aggressive behavior in fish species.

The selection of the appropriate biological markers for the study of the contaminant effect/low dose-response relationships is frequently a controversial issue. Freshwater fish are especially vulnerable to cadmium toxicity (Sorensen, 1991). The effects of cadmium on fish biology include growth retardation (Lemaire \& Lemaire, 1992), inhibition of calcium uptake in gills (Verbost et al., 1987), changes in normal metabolic patterns (Soengas et al., 1996; Almeida et al., 2001), and altered reproduction and egg quality (Lin et al., 2000). Fish promptly respond to cadmium and other contaminants with alterations in detoxification enzymes (Jimenez \& Stegeman, 1990), and it is well known that these enzymatic responses are modulated by several factors, among them temperature, age, nutritional status (Jimenez \& Stegeman, 1990), and oxygen availability (Wilhelm Filho, 1996).

Oxygen is an essential element for aerobic metabolism, since it is the terminal acceptor of electrons in oxidative phosphorylation. However, in certain conditions such as cadmium exposure (Novelli et al., 1998), electron flow may become uncoupled, leading to the production of reactive oxygen species (ROS). Reactive oxygen species, superoxide anion $\left(\mathrm{O}_{2}^{-}\right)$, hydroxyl radicals $(\mathrm{OH})$ and hydrogen peroxide $\left(\mathrm{H}_{2} \mathrm{O}_{2}\right)$ can elicit widespread damage to cells, such as lipoperoxidation of polyunsaturated membrane lipids. Lipoperoxidation is a free radical-mediated chain reaction, since it is self-perpetuating. The length of the propagation depends on the chain breaking antioxidant. Oxidative stress, defined as the imbalance between oxidants and antioxidant defenses (Nishiyama et al., 1998), may be related to both cadmium exposure and tissue damage.

Social stressors also affect fish metabolism, causing a physiological stress state (Fernandes \& Volpato, 1993; Alvarenga \& Volpato, 1995; Giaquinto \& Volpato, 1997; Damsgard \& Arne Mikol, 1998; Overli et al., 1998; Sakakura et al., 1998; Overli et al., 1999; Sakakura \& Tsukamoto, 1999; Hoglund et al., 2000). The physiological "fight or flight" responses to a stressor include catabolic reactions (Vijayan et al., 1997), and the magnitude of stress responses to social stress is inversely related to social status (Fernandes \& Volpato, 1993; Sakakura et al., 1998; Sakakura \& Tsukamoto,
1999). Since metabolic differences may affect antioxidant defenses, we hypothesize that antioxidant enzyme activities are modulated by social status in the cichlid Nile tilapia in response to cadmium contamination. Nile tilapia (Oreochromis niloticus) was chosen because it has an evident territorial aggressive behavior.

The major purpose of the present study was to investigate the possible link between cadmium exposure, hepatic markers of oxidative stress and aggressive motivation in Nile tilapia. We examined the effects of cadmium on aggressive behavior in order to determine social status. Since cadmium contamination frequently occurs, it would be of interest to see if oxidative stress markers are associated with aggressive behavior in fish.

\section{Material and Methods}

Twenty-four Nile tilapia (Oreochromis niloticus) with a mean mass of $36.04 \pm 2.70 \mathrm{~g}$ were purchased from CESP (Energy Company of São Paulo State,) Barra Bonita, São Paulo State, Brazil. Fish were acclimated for one month prior to the experiments. They were kept individually in glass aquaria (one fish per aquarium), with constantly aerated fresh water $(25 \mathrm{~L})$, under 12:12 light-dark cycle, temperature of $22-25^{\circ} \mathrm{C}$, dissolved oxygen $\left(\mathrm{DO}_{2}\right)$ of 7.38 to $7.81 \mathrm{mg} / \mathrm{L}, \mathrm{pH} 7.6$ to 7.7 , nitrite and ammonia lower than 0.05 and $0.01 \mathrm{mg} / \mathrm{L}$. The water parameters and quality were measured at the beginning and daily at the end of the experimental period. The fish were fed ad libitum with tropical fish chow (Purina Ltda, Campinas, SP, Brazil) with optimal protein concentration (38\%) for Oreochromis (James \& Sanpath, 1999). The animals were fed daily (3\% of body mass) in the morning (at 9:00 to 10:00 h) and the unfed diet remains were collected after $30 \mathrm{~min}$ and dried to constant weight. The food consumption was calculated as the difference between the offered and leftover food.

After acclimation, fish were weighed and randomly allocated to a control (group A) or cadmium-exposed group $\left(0.75 \mathrm{mg} / \mathrm{L}\right.$ of $\mathrm{Cd}^{++}$as $\mathrm{CdCl}_{2}$ ) (twelve isolated fish for each group, one fish per aquarium). The $96-\mathrm{h} \mathrm{LC}_{50}$ of $\mathrm{CdCl}_{2}$ for adult Nile tilapia was previously determined as $18.58 \mathrm{mg} / \mathrm{L}$ in the same freshwater conditions. There was $100 \%$ mortality in fish groups kept in water containing 40.96 and $81.92 \mathrm{mg} \mathrm{Cd} / \mathrm{L}$. In fish groups kept under 1.24 and $20.48 \mathrm{mg} \mathrm{Cd} / \mathrm{L}$, the mortality was $20 \%$ and $40 \%$, respectively. A concentrated solution of cadmium was prepared by dissolving $\mathrm{CdCl}_{2}$ in one liter of distilled water, and this mixture was diluted with tap water to obtain the desired concentration for the experiment (James \& Sanpath, 1999). Fish were exposed to cadmium for 15 days. The water was changed twice a week to maintain the environmental conditions and $\mathrm{Cd}^{++}$concentrations (Proença \& Bittencourt, 1994).

In the behavioral test, fish were paired for $1 \mathrm{~h}$ ( 6 pairs per group) on the $15^{\text {th }}$ day in glass aquaria (two fish per aquarium), with continuously aerated tap water $(25 \mathrm{~L})$. Fish behavior was videorecorded for quantification of the aggressiveness parameters. During this period, water parameters and quality 
were maintained as in the tanks exposed to the abovementioned conditions. To identify the dominant and submissive individual in each pair during social interaction, aggressive acts in each pair were recorded for 20- min observation sessions after the first observed attack. Immediately after the behavioral tests the animals were reweighed and sacrificed in order to obtain the liver. For the sacrifice procedure, each fish was anesthetized with benzocaine $(80 \mathrm{mg} / \mathrm{L})$ and killed by transecting the spinal cord. The liver was removed, weighed, frozen in liquid nitrogen and stored at $-80^{\circ} \mathrm{C}$ for later biochemical determinations.

For aggression quantification, confrontations were classified according to an agonistic profile or ethogram (Alvarenga \& Volpato, 1995; Barki \& Volpato, 1998). The level of aggression (number of attacks) and the latency to first attack (attack latency) of individual fish was determined from the videotaping. Aggression was evaluated as the total fight frequency for each pair, and by the time before the first fight began. One pair of the cadmium group did not fight and was therefore not considered in the analysis.

Biochemical Procedures. The frozen liver samples from each fish were thawed and homogenized using a teflon-glass Potter Elvejhem tissue homogenizer (1 min, $100 \mathrm{rpm}$ ) with 2 volumes of ice-cold medium containing $50 \mathrm{mM}$ imidazole, $150 \mathrm{mM}$ sucrose, $50 \mathrm{mM} \mathrm{KCl}, 1 \mathrm{mM}$ EDTA and $2 \mathrm{mM}$ reduced gluthatione (adjusted to $\mathrm{pH} 6.8$ with $\mathrm{HCl}$ ) (Mommsen et al., 1980). The homogenates were centrifuged at $10,000 \mathrm{~g}$ for 15 min at $4{ }^{\circ} \mathrm{C}$ (Pereira et al., 1998). The supernatants were used for glutathione peroxidase (GSH-Px, E.C. 1.11.1.9.), selenium dependent glutathione peroxidase (Se-GSH-Px), superoxide dismutase (SOD, E.C. 1.15.1.1.), $\mathrm{Cu}-\mathrm{Zn}$ superoxide dismutase (Cu-Zn SOD), catalase (CAT, E.C. 1.11.1.6), and lipoperoxide determinations.

Lipoperoxide was measured colorimetrically using thiobarbituric acid (TBA; Sigma) (Satoh, 1978). Malondialdehyde standard was prepared from $20 \mathrm{mM}$ 1,1,3,3tetraethoxypropane (Sigma). Following incubation at $37^{\circ} \mathrm{C}$ for $60 \mathrm{~min}$, the samples were poured into test tubes containing 1 $\mathrm{mL}$ of $20 \%$ trichloroacetic acid. One milliliter of $0.67 \%$ TBA, in $2 \mathrm{M}$ sodium sulfate, was added. Following $15 \mathrm{~min}$ of boiling and subsequent cooling, the samples were centrifuged 10 min at $1085 \mathrm{~g}$ and the optical density of the supernatant fraction was read at $530 \mathrm{~nm}$.

Glutathione peroxidase was assayed using $0.15 \mathrm{M}$ phosphate buffer, pH 7.0, containing 5 mM EDTA(Sigma), 0.1 $\mathrm{mL}$ of $0.0084 \mathrm{M}$ NADPH, 50 units GSSG-reductase (Sigma), $0.01 \mathrm{~mL}$ of $1.125 \mathrm{M} \mathrm{NaN}_{3}$ (sodium azide) and $0.1 \mathrm{~mL}$ of $0.15 \mathrm{M}$ GSH (glutathione, reduced form). Total glutatione peroxidase activity was determined using cumene hydroperoxide (1.5 $\mathrm{mM}$ ) as substrate, and the selenium enzyme was measured with $0.25 \mathrm{mM} \mathrm{H}_{2} \mathrm{O}_{2}$ as the substrate (Hopkins \& Tudhope, 1973).

Superoxide dismutase activity was determined based on the ability of the enzymes to inhibit the reduction of nitro blue tetrazolium (NBT; Sigma), which was generated by 37.5
$\mathrm{mM}$ hydroxylamine (Carlo Erba, Italy) in alkaline solution (Crouch et al., 1981). The assay was performed in $0.5 \mathrm{M}$ sodium carbonate ( $\mathrm{pH}$ 10.2) with EDTA. The reduction of NBT (by $\mathrm{O}_{2}^{-}$) to blue formazan was measured spectrophotometrically at $560 \mathrm{~nm}$. The rate of NBT reduction in the absence of tissue was used as the reference rate. An assay control in the absence of hydroxylamine was used to determine the reduction of NBT by agents other than superoxide (Otero et al., 1983). One unit of SOD was defined as the amount of protein needed to decrease the reference rate to $50 \%$ of maximum inhibition. All data were expressed in units of SOD per mg protein. Cu-Zn SOD was assayed using a chloroform-ethanol mixture.

Catalase was determined with phosphate buffer, $\mathrm{pH}$ 7.0, at $240 \mathrm{~nm}$. The data were expressed as Kat.f. units (Aebi, 1974).

Data Analyses. Specific growth rate was calculated as $\mathrm{SGR}=100$ $\left(\ln \mathrm{W}_{\mathrm{f}}-\ln \mathrm{W}_{\mathrm{i}}\right) \mathrm{Dt}^{-1}$, where $\mathrm{W}_{\mathrm{f}}$ is the final and $\mathrm{W}_{\mathrm{i}}$ the initial weight of the fish and $\mathrm{Dt}$ is the time interval of cadmium exposure (Fu et al., 1998).

Biochemical parameters are presented as means \pm SD. Significance of difference was tested by analysis of variance (ANOVA) in conjunction with Tukey's test. Aggressiveness and growth parameters were analyzed using the unpaired Student's $t$ test. Differences were considered significant at $\mathrm{p}$ $<0.05$ (Zar, 1974).

\section{Results}

No fish died during the acclimation period or throughout the 15 days of the experimental period. A statistically significant decrease in food intake and specific growth rate was observed in cadmium-exposed Nile tilapia when compared with control fish (Table 1). However, no differences were seen in final gross body mass between dominate and subordinate in each group individually, nor between control and cadmiumexposed fish (Table 1).

Nile tilapia aggressiveness performance was affected by cadmium exposure (Fig. 1).

Latency of first fight was higher for the cadmium-exposed pairs than for the controls, and the total fight frequency was higher for the control pairs.

No effect of cadmium exposure and social status was observed on Se-GSH-Px and Cu-Zn SOD liver activities. GSHPx activity was decreased in subordinates of cadmium-exposed pairs. SOD was decreased for the control subordinate fish.

Table 1. Effect of cadmium $\left(\mathrm{CdCl}_{2}\right)$ exposure on Nile tilapia. * $=$ Statistically different from control, $\mathrm{P}<0.05$.

\begin{tabular}{l|c|c}
\hline \multicolumn{1}{c|}{ Growth parameter } & Control & $\begin{array}{c}\text { Cadmium } \\
0.75 \mathrm{mg} / \mathrm{L}\end{array}$ \\
\hline Initial body weight $(\mathrm{g})$ & $37.92 \pm 6.57$ & $39.18 \pm 6.94$ \\
Final body weight $(\mathrm{g})$ & $38.62 \pm 6.57$ & $38.75 \pm 6.59$ \\
Specific growth rate (\% day) & $0.41 \pm 0.12$ & $-0.10 \pm 0.63^{*}$ \\
Food intake (\% body weight / day) & $1.52 \pm 0.30$ & $1.06 \pm 0.38^{*}$ \\
\hline
\end{tabular}



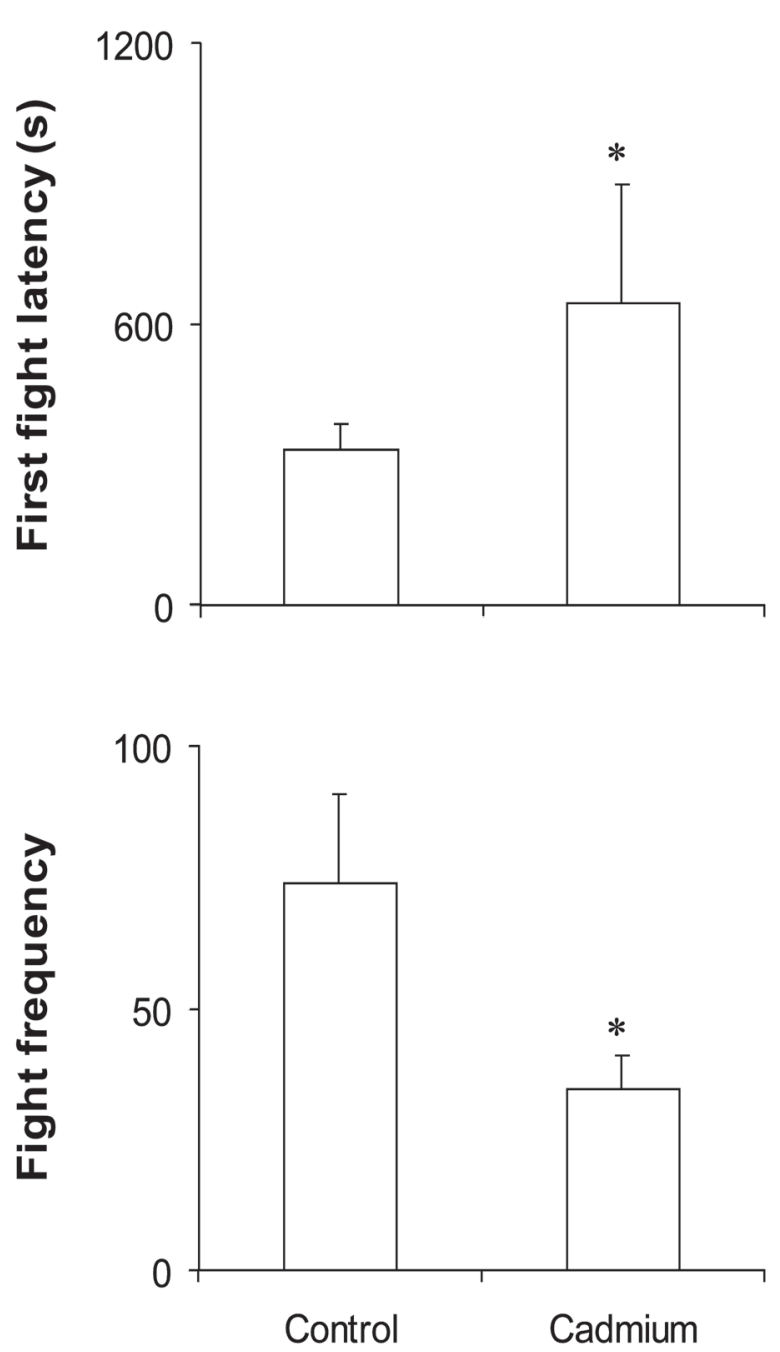

Fig. 1. Effects of cadmium exposure on aggressiveness parameters of Nile tilapia. Values are means $( \pm \mathrm{SD}) .{ }^{*}=$ Statistically different from control.

CAT activity was lower in the subordinate controls than in dominants, whereas in cadmium-exposed pairs the effect of social status was not detected. CAT activities in cadmiumexposed pairs were higher than for the control pairs. Lipoperoxide concentrations for the subordinates of control pairs were increased relative to the control dominant. This difference was not observed in cadmium-exposed pairs, but lipoperoxide concentrations were higher in cadmium-exposed fish than in both subordinate and dominant controls. (Table 2).

\section{Discussion}

Since Nile tilapia is the most common cichlid cultured for human consumption (Lin et al., 2000), studies on metal toxicity in these organisms are important. As a non-degradable cumulative pollutant, cadmium can alter trophic levels for centuries, and freshwater Nile tilapia is particularly vulnerable to its exposure (Almeida et al., 2001). Although free radicalmediated cellular damage and ROS may contribute to cadmium's mechanism of toxicity (Manca et al., 1991; Novelli Filho et al., 2000), there is little information on the effect of cadmium exposure on markers of oxidative stress in social fish. In the present study, we observed that cadmium decreased aggression and growth in Nile tilapia.

No difference was observed in gross body mass, but food intake and specific growth rate (SGR) were decreased in cadmium-exposed fish. Effects on growth are expected when these animals are exposed to chemical pollutants, if this exposure is sufficient to produce a stress response (Wendelaar Bonga, 1997). Stress-induced reduction in growth is a wellrecognized effect in fish (Barton \& Iwama, 1991; Wendelaar Bonga, 1997). Body weight loss induced by cadmium exposure has also been reported for rodents (Bomhard et al., 1999). The decrease in the SGR of the Nile tilapia studied herein may be related to the concomitant decrease in food intake (Table 1). Almeida et al. (2001) observed no significant effect of cadmium exposure $\left(\mathrm{CdCl}_{2}\right)$ at $0.32 \mathrm{mg} / \mathrm{L}$ to $2.56 \mathrm{mg} / \mathrm{L}$ on these growth parameters in tilapia. However, these authors exposed the fish to $\mathrm{Cd}^{++}$for less time (7 days) than the Nile tilapia of the present study. Almeida et al. (2001) also showed decreased protein content in white muscles by cadmium exposure, which could be related to decreased SGR.

Aggressiveness was severely affected by cadmium exposure. In the pairs exposed to cadmium, the first fight occurred about 2 times later than in control pairs, and total fight frequency was about half that of the controls. Hence, we can conclude that cadmium decreased intraspecific aggression in Nile tilapia. Accordingly, a reduction in the aggressiveness of Nile tilapia has been observed as an effect of toxic agents, such as trichlorfon (Hmoud et al., 1998), and also for another fish species, Therapon jarbua, exposed to DDT (Lingaraja et al., 1979).

The most obvious effect of cadmium exposure was the increased hepatic lipid peroxidation. Lipoperoxide generation was markedly more elevated in pairs of Nile tilapia exposed to cadmium than in control (Table 2). Other studies have reported

Table 2. Effect of cadmium exposure $\left(\mathrm{CdCl}_{2}\right)$ on oxidative stress markers in liver of Nile tilapia. Mean $( \pm \mathrm{SD})$ values that do not share the same letter for each parameter are statistically different $(\mathrm{P}<0.05)$.

\begin{tabular}{lcccc}
\hline \multirow{2}{*}{ Biochemical parameter } & \multicolumn{2}{c}{ Control } & \multicolumn{2}{c}{ Cadmium 0.75 mg/L } \\
\cline { 2 - 5 } & Dominate & Subordinate & Dominate & Subordinate \\
\hline Lipoperoxide (mmol/g tissue) & $0.23 \pm 0.03^{\mathrm{a}}$ & $0.26 \pm 0.04^{\mathrm{b}}$ & $0.40 \pm 0.12^{\mathrm{c}}$ & $0.31 \pm 0.06^{\mathrm{c}}$ \\
Se-GSH - Px (U/mg tissue) & $4.94 \pm 2.24^{\mathrm{a}}$ & $4.70 \pm 2.70^{\mathrm{a}}$ & $5.35 \pm 2.12^{\mathrm{a}}$ & $3.40 \pm 2.21^{\mathrm{a}}$ \\
GSH - Px (U/mg tissue) & $16.50 \pm 4.49^{\mathrm{b}}$ & $13.84 \pm 4.12^{\mathrm{b}}$ & $25.16 \pm 13.90^{\mathrm{b}}$ & $2.19 \pm 1.70^{\mathrm{a}}$ \\
SOD (U/mg protein) & $191.31 \pm 47.8^{\mathrm{b}}$ & $104.70 \pm 24.0^{\mathrm{a}}$ & $186.40 \pm 40.0^{\mathrm{b}}$ & $176.10 \pm 39.4^{\mathrm{b}}$ \\
Cu/Zn - SOD (U/mg protein) & $132.71 \pm 53.4^{\mathrm{a}}$ & $109.20 \pm 22.2^{\mathrm{a}}$ & $113.70 \pm 44.4^{\mathrm{a}}$ & $76.0 \pm 18.8^{\mathrm{a}}$ \\
CAT (Kat.f) & $9.74 \pm 3.81^{\mathrm{b}}$ & $3.70 \pm 1.75^{\mathrm{a}}$ & $29.32 \pm 13.51^{\mathrm{c}}$ & $15.45 \pm 4.2^{\mathrm{c}}$ \\
\hline
\end{tabular}


that lipid peroxidation is a consequence of cadmium exposure in both fish and mammals (Manca et al., 1991; Oner et al., 1994; Novelli et al., 1999). Lipoperoxide formation was increased by cadmium exposure, independent of social status. However, in the control pairs, subordinate fish had more lipoperoxide formation than dominant fish (Table 2). These results show that social stress may induce lipid peroxidation.

Social stress is well recognized as a potential stressor for some fish species (Hoglund et al., 2001; Volpato \& Fernandes, 1994; Damsgard \& Arne Mikol, 1998; Sakakura et al., 1998; Overli, et al., 1999), but the magnitude of stress is related to social status (Fernandes \& Volpato, 1993; Sakakura et al., 1998; Sakakura \& Tsukamoto, 1999). The stress response is a catabolic reaction (Vijayan et al., 1997), and if subordinates show a response of higher magnitude, they may have an increase in metabolism inducing higher lipid peroxidation than in dominant fish. This explanation supports the possibility of social stress causing elevated lipoperoxidation in fish.

Tissue and cell membrane lipoperoxidation caused by ROS have been considered to be proportional to antioxidant content (Novelli Filho et al., 2000). SOD catalyzes the destruction of $\mathrm{O}_{2}^{-}$by dismutation and $\mathrm{H}_{2} \mathrm{O}_{2}$ formation. Catalase and GSH-Px catalyze the conversion of hydrogen peroxide to water.

No effects of cadmium exposure on social status were observed on Se-GSH-Px and Cu-Zn-SOD activities. However, CAT and SOD activities were decreased in subordinate controls compared to dominant control fish. Thus, social status induced liver increased lipoperoxide due decreased CAT and SOD activities. The superoxide radical and hydrogen peroxide contributed to liver peroxidation due to social status. Cadmium exposure caused an elevation in CAT activity, independent of social status. Only GSH-Px was affected concomitantly by both social status and cadmium exposure. GSH-Px activity was decreased in liver of subordinate fish exposed to cadmium (Table 2), indicating that hydrogen peroxide has an important role in increased hepatic lipoperoxidation of cadmium-exposed fish.

Cadmium-exposed fish showed an enzymatic response profile with high activity for SOD and CAT, but the subordinates of this group showed a decrease in GSH-Px activity. This enzymatic response of GSH-Px may have occurred because social stress causes a higher increase in metabolism, inducing a greater oxygen uptake in subordinates (Alvarenga \& Volpato, 1995). Thus, subordinate stress decreased GSH-Px activity, while lipoperoxide was increased in fish exposed to cadmium. Metals are known to interfere with these physiological processes and can affect social structures (Sloman, 2007). Asagba et al. (2008) observed that the accumulation of Cd and its effect on SOD and LPO in the catfish Clarias gariepinus is dependent on concentration, tissue and time.

In conclusion, cadmium exposure affected antioxidant enzymes and oxidative stress in Nile tilapia and influenced its social status, since subordinate fish exposed to cadmium responded with lower antioxidant enzymes compared to dominant fish.

\section{Acknowledgments}

We thank Gilson Luis Volpato, Department of Physiology, I.B., Universidade Estadual Paulista, UNESP, Botucatu, for providing research space and valuable help during the course of these experiments. This study was supported by grants from FAPESP (Fundação de Amparo à Pesquisa do Estado de São Paulo) and CNPq (Conselho Nacional de Desenvolvimento Científico e Tecnológico).

\section{Literature Cited}

Abdul Farah, M., B. Ateeq, M. Niamar Ali, R. Sabir \& W. Ahmad. 2004. Studies on lethal concentrations and toxicity stress of some xenobiotics on aquatic organisms. Chemosphere, 55: 257-265.

Asagba, S. A., G. E. Eriyamremu \& M. E. Igberaese. 2008. Bioaccumulation of cadmium and its biochemical effect on selected tissues of the catfish (Clarias gariepinus). Fish Physiology and Biochemistry, 34: 61-69.

Aebi, H. 1974. Methods of enzymatic analysis. Verlag Chemic Weinheim. Bergmeyer, V.H. (Eds.). Germany, 565p.

Almeida, J. A., E. L. B. Novelli, M. Dal Pai Silva \& R. Alves Jr. 2001. Environmental cadmium exposure and metabolic responses of the Nile tilapia, Oreochromis niloticus. Environmental Pollution, 114: 169-175.

Alvarenga, C. M. D. \& G. L. Volpato. 1995. Agonistic profile and metabolism in alevins of the Nile tilapia. Physiology Behavior, 57: 75-80.

Barki, A. \& G. L. Volpato. 1998. Early social environmental and the fighting behaviour of young Oreochromis niloticus (Pisces, Cichlidae). Behaviour, 135: 913-929.

Barton, B. A. \& G. K. Iwama. 1991. Physiological changes in fish from stress in aquaculture with emphasis on the response and effects of corticosteroids. Reviews of Fish Disease, 1: 3-26.

Bomhard, E. M., D. Maruhn \& M. Rinke. 1999. Time course of chronic oral cadmium nephrotoxicity in Wistar rats: excretion of urinary enzymes. Drug and Chemical Toxicology, 22: 679-703.

Cope, W. G., J. Wiener, M. T. Steingraeber \& G. J. Atchison. 1994. Cadmium, metal-binding proteins, and growth in bluegill (Lepomis macrochirus) exposed to contaminated sediments from the upper Mississippi River basin. Canadian Journal of Fish and Aquatic Science, 51: 1356-1367.

Crouch, R. K., S. C. Gandy \& G. Kimsey. 1981. The inhibition of islet superoxide dismutase by diabetogenic drugs. Diabetes, 30: 235-241.

Damsgard, B. \& A. Arne Mila. 1998. Feeding, smelting and social interactions during seawater acclimation in Atlantic salmon Salmo solar L. Aquaculture, 168: 7-16.

Fernandes, M. O. \& G. L. Volpato. 1993. Heterogeneous growth in the Nile tilapia: social stress and carbohydrate metabolism. Physiology and Behaviour, 54: 319-323.

Fu, C., Y. Cui, S. S. O. Hung \& Z. Zhu. 1998. Growth and feed utilization by $\mathrm{F}_{4}$ human growth hormone transgenic carp fed diets with different protein levels. Journal of Fish Biology, 53: 115-129.

Giaquinto, P. C. \& G. L. Volpato. 1997. Chemical communication, aggression, and conspecific recognition in the Nile tilapia. Physiology and Behaviour, 62: 1333-1338.

Hmoud, F. A., S. A. A. Ali \& A. Zubair. 1998. Carbohydrate metabolism and ethological responses of cichlid fish, Oreochromis niloticus exposed to trichlorfon. Geobios Jodhpur, 25: 10-16.

Hoglund, E., P. H. M. Balm \& S. Winberg. 2000. Skin darkening, a potential social signal in subordinate Arctic charr (Salvelinus alpinus): the role of brain monoamines and pro-opiomelanocortinderived peptides. Journal of Experimental Biology, 203: 171-1721.

Hoglund, E., N. Kolm \& S. Winberg. 2001. Stress-induced changes in brain serotonergic activity, plasma cortisol and aggressive 
behaviour in Artic charr (Salvelinus alpinus) is counteracted by L-DOPA. Physiology and Behaviour, 74: 381-389.

Hopkins, J. \& G. R. Tudhope. 1973. Glutathione peroxidase in human red cells in health and disease. British Journal of Haematology, 25: 563-575.

James, R. \& K. Sanpath. 1999. Effects of zeolite reduction of cadmium toxicity in water and a freshwater fish, Oreochromis niloticus. Bulletin of Environmental Contamination Toxicology, 62: 222-229.

Jimenez, B. D. \& J. J. Stegeman. 1990. Detoxication enzymes as indicators of environmental stress on fish. Pp. 67-79. In: Adams, S. M. (Eds). American Fisheries Symposium 8, Maryland.

Klaassen, C. D. \& J. Liu. 1997. Role of metallothionein in cadmiuminduced hepatotoxicity and nephrotoxicity. Drugs and Metabolism Review, 29: 79-102.

Lefebvre, K.A., V. L.Trainer \& N. L. Scholz. 2004. Morphological abnormalities and sensorimotor deficits in larval fish exposed to dissolved saxitoxin. Aquatic Toxicology, 66: 159-170.

Lemaire, G. S. \& P. Lemaire. 1992. Interactive effect of cadmium and benzopyrene on cellular structure and biotransformation enzymes of the liver of the European eel. Aquatic Toxicology, 22: 145-160.

Lin, H. C., S. C. Hsu \& P. P. Hwang. 2000. Maternal transfer of cadmium tolerance in larval Oreochromis mossambicus. Journal of Fish Biology, 57: 239-249.

Lingaraja,T., P. S. B. Rao \& V. K. Venugopalan. 1979. DDT induced ethological changes in estuarine fish. Environmental Biology of Fish, 4: 83-88.

Manca, D., A. C. Ricard, B. Trottier \& G. Chevalier. 1991. Studies on lipid peroxidation in rat tissue following administration of low and moderate doses of cadmium chloride. Toxicology, 67: 303-323.

Mommsen, T. P., C. J. French \& P. W. Hochachka. 1980. Sites and patterns of protein and amino acid utilization during spawning migration of salmon. Canadian Journal of Zoology, 58: 1758-1799.

Nakayama, K, Y. Oshima, T. Yamaguchi, Y. Tsuruda, I. J. Kang, M. Kobayashi, N. Imada \& T. Honjo. 2004. Fertilization success and sexual behavior in male medaka Oryzias latipes, exposed to tributyltin. Chemosphere, 55: 1331-1337.

Nishiyama, Y., H. Ikeda, N. Haramaki, N. Yoshida \& T. Imaizume. 1998. Oxidative stress is related to exercise intolerance in patients with heart failure. American Heart Journal, 135:115-120.

Novelli, E. L. B., A. M. Lopes, A. S. E. Rodrigues, J. L. V. B. Novelli Filho \& B. O. Ribas. 1999. Superoxide radical and nephrotoxic effect of cadmium exposure. International Journal of Environment and Health Research, 9: 109-116.

Novelli, E. L. B., E. P. Vieira, N. L. Rodrigues \& B. O. Ribas. 1998. Risk assessment of cadmium toxicity on hepatic and renal tissues of rats. Environmental Research, 79: 102-105.

Novelli Filho, J. L. V. B., E. L. B. Novelli \& B. O. Ribas. 2000. Effect of alpha tocopherol on superoxide radical and toxicity of cadmium exposure. International Journal of Environmental Health Research, 10: 125-134.

Nriagu, J. O., H. K. T. Wong, G. Lawson \& P. Daniel. 1998. Saturation of ecosystems with toxic metals in Sudbury basin, Ontario, Canada. Science and Total Environment, 233: 99-117.

Oner, G., N. I. Uysol \& U. K. Senturk. 1994. Role of lipid peroxidation in cadmium-induced impairment of the gastric mucosal barrier. Food and Chemical Toxicology, 32: 799-804.

Otero, J., P. Toni \& P. Garcia Morato. 1983. Superoxido dismutasa: metodo para su determinacion. Revista Iberoamericana Investigaciones Clinica, 2: 121-127.

Overli, O., C. A. Harris \& S. Winberg. 1999. Effects of fights for social dominance, and the establishment of dominancesubordinate relationships, on brain monoamines and cortisol in rainbow trout. Brain Behaviour and Evolution, 54: 263-275.

Overli, O., S. Winberg, B. Damsga ${ }^{\circ}$ rd \& M. Jobling. 1998. Food intake and spontaneous swimming activity in Arctic charr (Salvelinus alpinus L.): role of brain serotonergic activity and social interaction. Canadian Journal of Zoology, 76: 1366-1370.

Pereira, B., L. F. B. P. Costa Rosa, E. J. H. Bechara, P. Newsholme \& R. Curi. 1998. Changes in TBARS content and superoxide dismutase, catalase and glutathione peroxidase activities in the lymphoid organs and skeletal muscles of adrenodemedullated rats. Brazilian Journal of Medical and Biological Research, 31: 827-833.

Proença, C. E. M. \& P. R. L. Bittencourt. 1994. Manual de piscicultura tropical, Ibama, Brasília, 78p.

Provias, J. P., C. A. Ackerley \& L. E. Becker. 1994. Cadmium encephalopathy: a report with elemental analysis and pathological findings. Acta Neuropathology, 88: 583-586.

Scott, G. R. \& K. A. Sloman. 2004. The effects of environmental pollutants on complex fish behavior: integrating behavioral and physiological indicators of toxicity. Aquatic Toxicology, 68: 369-392.

Sloman, K. A. 2007. Effects of trace metals on salmonid fish: The role of social hierarchies. Applied Animal Behaviour Science, 104: 326-345.

Sloman, K. A., G. R. Scott, Z. Diao, C. Rouleau, C. M. Wood \& D. G. McDonald. 2003. Cadmium affects the social behaviour of rainbow trout, Oncorhynchs mykiss. Aquatic Toxicology, 65: 180-185.

Sakakura, Y., M. Tagawa \& K. Tsukamoto. 1998. Whole-body cortisol concentrations and ontogeny of aggressive behaviour in yellowtail (Seriola quinqueradiata Temminck \& Schlegel; Carangidae). General and Comparative Endocrinology, 109: 286-292.

Sakakura, Y. \& K. Tsukamoto. 1999. Ontogeny of aggressive behaviour in schools of yellowtail, Seriola quinqueradiata. Environmental Biology of Fish, 56: 231-242.

Satoh, K. 1978. Serum lipid peroxide in cerebrovascular disorders determined by a new colorimetric method. Clinic Chemical Acta, 90: 37-43.

Shen, H. M. \& S. Sangiah. 1995. $\mathrm{Na}^{+}, \mathrm{K}^{+}$-ATPase, glutathione and hydroxyl free radicals in cadmium chloride-induced testicular toxicity in mice. Archives of Environmental Contamination and Toxicology, 29: 174-179.

Soengas, E. M., B. Carballo, M. D. Andres \& J. A. R. Vieira. 1996. Effect of an acute exposure to sublethal concentrations of cadmium on liver carbohydrate metabolism of Atlantic salmon (Salmo salar). Bulletin of Environmental Contamination and Toxicology, 57: 625-631.

Sorensen, E. M. 1991. Cadmium. Metal poisoning in fish. CRC Press, Boca Raton, Florida.

Verbost, P. M., G. Flik, A. C. Lock \& S. E. Wendelaar Bonga. 1987. Cadmium inhibition of $\mathrm{Ca}^{++}$uptake in rainbow trout gills. American Journal of Physiology, 253: 216-221.

Vijayan, M.M., C.Pereira, E.Gordon Grau \& G.K.Iwama. 1997. Metabolic responses associated with confinement stress in tilapia: the role of cortisol. Comparative Biochemical Physiology, 116: 89-95.

Volpato, G. L. \& M. O. Fernandes. 1994. Social control of growth in fish. Brazilian Journal of Medical and Biological Research, 27: 797-810.

Wendelaar Bonga, S. E. 1997. The stress response in fish. Physiology Review, 77: 591-625.

Wilhelm Filho, D. 1996. Fish antioxidant defenses: a comparative approach. Brazilian Journal of Medical and Biological Research, 29: 1735-1742.

Yilmaz, M., A. \& Gül, E. Karaköse. 2004. Investigation of acute toxicity and the effect of cadmium chloride $(\mathrm{CdCl} 2 . \mathrm{H} 2 \mathrm{O})$ metal salt on behavior of the guppy (Poecilia reticulatus). Chemosphere, 56: 375-380.

Zar, J. H. 1974. Multiple comparisons. Biostatistical analysis. Prentice Hall, New York.

Accepted October 2008 Published March 31, 2009 